\title{
SECURED REAL ESTATE LOAN PREPAYMENT AND THE PREPAYMENT PENALTY
}

Over fifty per cent of all home mortgage debt retirement in California apparently occurs prior to maturity of the debt. ${ }^{1}$ Some lenders estimate that their residential loan portfolios undergo a complete turnover every six to eight years. ${ }^{2}$ Lenders explain the extent of mortgage prepayment by the high resale rate in residential property. ${ }^{3}$ With rising prices, most buyers are unable or unwilling to make a down payment of the difference between the purchase price and the balance due on the seller's existing loan. ${ }^{4}$ Nor will the buyer wish to assume the existing loan and give the seller a note secured by a second trust deed with its normally higher rate of interest, if the property will support a larger initial loan. The average buyer, therefore, insists on refinancing the property, thus forcing the seller to pay off his existing loan in advance of maturity.

The borrower ${ }^{5}$ attempting to prepay the mortgage often finds that the lender will refuse a tender of the principal and earned interest unless an additional charge is paid. This Comment will examine the riglit of a lender to refuse prepayment, the practice of exacting a prepayment charge, the judicial protection available to a borrower faced with an excessive prepayment cliarge, and the possibility of regulating mortgage prepayment by statute.

\section{THE.RIGHT TO PREPAY AND THE PREPAYMENT PENALTY}

Absent an applicable state statute or federal loan regulation, ${ }^{6}$ the California borrower cannot compel his lender to accept payment of a mortgage debt before

1 Figures compiled by the Federal Home Loan Bank Board for the years 1958 through 1961 show that of eighteen to nineteen billion dollars paid annually to retire mortgages on selected residential property, ten to eleven billion dollars was paid before maturity of the debt or installments. The balance represents amortized payments, the total sum paid in installments or at maturity. These figures do not include mortgage retirement handled by banks, savings and loan associations not members of the Federal Savings and Loan Insurance Corporation, or other real estate lenders. It seems probable, however, that the percentage ratio of prepayments would be approximately the same. Savings AND Home FINANCE CHART Book, 1959-1962 (1963).

2 Interviews were conducted with executives of over twenty commercial lending institutions in the San Francisco Bay Area, including financial and legal representatives of banks, savings and loan associations, insurance companies, and mortgage brokers. In support of the lenders' estimates, the Housing and Home Finance Agency reports that 47,552 of 100,000 residential mortgage loans insured by the Federal Housing Authority between 1935 and 1959 did not survive beyond the eighth loan year. 1961 H.H.F.A. ANN. REP. 149. With such a high turnover rate hased on national averages, it is entirely credible that many California lenders could experience complete portfolio turnover within an eight year period.

3 See Camifornia Savings and Loan League, Data Book (1963), for various comparison charts by which real estate turnover in California can be approximated. Exact data is unavailable.

4 For example: On a purchase price of $\$ 20,000$ with an existing loan balance of $\$ 10,000$, a buyer, to avert refinancing or resorting to a high interest "second" trust deed note, would need a $\$ 10,000$ down payment.

$\sigma$ For simplicity, the terms borrower and lender shall refer respectively to the debtor and creditor in any number of secured real property loan transactions. The discussion shall deal basically with the mortgage or California deed of trust; however, much of the Comment may also have application in the installment land contract.

6 There are several federal regulations, governing loan terms in federally insured real estate loans, and California statutes which control prepayment rights in a limited number of loan transactions. See notes $92-98$ infra and accompanying text. 
maturity. ${ }^{7}$ The lender undoubtedly has the right to refuse a premature tender of principal and accrued interest, and no action will lie against him to obtain the discharge of the mortgage. ${ }^{8}$ As it is often essential for a borrower to prepay an existing loan in order that a buyer inay refinance in conjunction with a sale of the property, the right to prepay must soinehow be acquired from the lender.

As a inatter of standard lending practice, a sum of inoney is exacted from the borrower as a charge for the right to prepay. The charge, commonly known as a prepayment penalty, may be either the option or non-option type. The non-option penalty exists where the loan agreement omits any mention of prepayment rights. When the borrower attempts to prepay, the lender is in a position to demand a penalty for allowing prepayment. Conversely, the option penalty is actually stipulated in the loan agreement as a condition of the right to prepay. While the non-option penalty is favored by inany lenders for its flexibility, the prepayment option appears to be more common. ${ }^{9}$

It unight seem that lenders would compete in offering attractive prepayment rights to secure loan business. Competition, however, is not nearly so keen with regard to prepayment terms as it is to interest rates and loan service charges. When negotiating a loan, an unsophisticated borrower will rarely contemplate problems regardimg repayment before maturity. Thus unless the particular lender customarily includes a prepayment option, the average borrower is not likely to ask for one. Even if an option is included, lenders indicate that perhaps one borrower in one hundred seriously concerns hinself with its terms. ${ }^{10}$ Moreover, in California there is virtually no statutory control over the prepayment of secured real estate loans. ${ }^{11}$

In such an atmosphere, lacking both competitive checks and statutory regulations, abuses are hikely. Where there is no prepayment option, the prepaying borrower is at the lender's inercy. While most reputable lenders have standardized charges that often turn out to be reasonable in particular circumstances, ${ }^{12}$ lenders

7 This rule, apparently based on the principle that a contract is enforceable according to its terms, seems to have been adopted by the California Supreme Court without discussion or citation of authority. Smiddy v. Grafton, 163 Cal. 16, 19, 124 Pac. 433, 435 (1912). The rule has never been directly reaffirmed, yet it is necessarily presumed by subsequent cases dealing with prepayment penalties and usury. See McCarty v. Mellinkoff, 118 Cal. App. 11, 4 P.2d 595 (1931). It seems firmly established elsewhere. See 59 C.J.S. Mortgages $\S 447$, at 695 (1959); 2 Jones, MORTGAGes $\$ 1137$ (8th ed. 1928); 26 R.C.L. Tenders $\$ 14$; cases cited note 8 infra.

8 See Bowen v. Juhus, 141 Ind. 310, 40 N.E. 700 (1895); Moore v. Kime, 43 Neb. 517, 61 N.W. 736 (1895) ; Duke v. Pugh, 218 N.C. 580, 11 S.E.2d 868 (1940); Henderson v. Guest, 197 Okla. 443, 172 P.2d 605 (1946); Pederson v. Fisher, 139 Wash. 28, 245 Pac. 30 (1926). A borrower presumably could compel his lender to discharge the mortgage upon tender-no natter how premature- of the principal and full interest computed to the date of maturity. There seem to be no Cahifornia cases. See 2 Jones, Mortcages $\$ 1137$ (8th ed. 1928).

9 The survey of Bay Area lending practices revealed that, while savings and loan associations, insurance companies, and mortgage brokers tend to favor a prepayment option with a penalty clause, commercial banks seem to favor the non-option device.

10 Most lenders were candid enough to admit that prepayment penalty charges constitute an important source of income revenue, ranking just behind interest and loan charges. Rather than risking a comparison of penalty charges, a lender can be expected to avoid the subject unless a borrower specifically brings it up.

11 Neither general usury laws nor specific regulations of California real estate loan practices affect the prepayment penalty charge. See discussion and accompanying text at notes 19-37, 92-98 infra.

12 Of the lenders interviewed using the non-option approach, all bad some sort of policy schedule for exacting prepayment penalties. One very large bank recommends that its lending 
can easily take advantage of the situation. A recent New York case, ${ }^{13}$ for example, involved a 2,000 dollar penalty for a prepayment of less than 15,000 dollars. Many California lenders recalled similar penalties which were not hitigated only because the borrower lacked an effective remedy. In prepayment option agreements, although penalty terms are often moderate, ${ }^{14}$ there are many lenders using penalty clauses calling for five per cent, or more, of the original principal. Even where the penalty may be relatively modest, the frequent inclusion of a hidden lock-in clause, ${ }^{15}$ prohibiting prepayment in the first few years of the loan, often results in the borrower being placed in the same position he would be in without a prepayment option. Another lending practice, common in both option and non-option penalty situations, is the use of the penalty to minimize the effects of loan competition. A lender may offer to waive his right to all or a part of a penalty if the borrower will agree to finance his new purchase through the same lender. Faced with the immediate payment of a stiff prepayment penalty, the borrower will often forego better loan terms from another lender. Competition in the money market may be dulled because the lender, willing to loan at a lower rate of interest, is frustrated by prepayment tactics, with the borrowing public suffering the long term losses. ${ }^{16}$ Thus excessive prepayment penalties can be harmful not only to the individual borrower, hard pressed to meet the penalty demands of his lender, but to the general borrowing public as well.

II

\section{JUDICIAL PROTECTION FROM EXCESSTVE PREPAYMENT PENALTIES}

\section{A. An Early Attack on the Penalties-Usury}

Excessive prepayment penalty charges frequently have been challenged in the courts. ${ }^{17}$ The principal argument advanced by the borrower is usury. ${ }^{18}$ This argu-

officers charge between $11 / 2 \%$ and $21 / 2 \%$ of the original principal when a loan is retired before its tenth anniversary. In some situations, where a large loan has been on the books for many years, even this small percentage could be a harsb penalty.

13 Feldman v. Kings Highway Sav. Bank, 278 App. Div. 589, 102 N.Y.S.2d 306, aff'd mem. 303 N.Y. 675,102 N.E.2d 835 (1951).

14 A typical penalty clause calls for six months' uncarned interest on prepayments exceeding $20 \%$ of the original principal in any calendar year.

15 An example of a common lock-in clause reads: "The privilege is granted of making additional payments on the principal on payment dates after three years froin the date of this note, subject to the payment of a prepayment fee equal to six months' advance interest on the amount of the principal so paid." The lock-in feature is at least partially "hidden" by the affirmative terminology.

16 Lenders will also agree to waive the penalty when a borrower refinances at a higher rate of interest, or when a borrower is able to contract with the buyer of his property to finance through the borrower's lender-again at a higher rate of interest.

17 Cases involving mortgage prepayment penalty clauses, other than attacks on the amount of the penalties, have concerned interpretation problems. For example, when a mortgaged property is destroyed by fire, and, by the terms of the mortgage, the debt must be directly satisfied out of the insurance proceeds, the question arises as to whether the mortgagee is entitled to a prepayment penalty. It has been held that unless the penalty clause expressly covers such situations, no penalty is due. Chestnut Corp. v. Bankers Bond \& Mortgage Co., $395 \mathrm{~Pa} .153,149$ A.2d 48 (1959); but see Re Anderson Furniture Co., 39 N.B. 139 (1908). In a non-option situation it may similarly be assumed that no penalty would be due.

18 But see Cook v. Washington Mut. Sav. Bank, 143 Wash. 145, 254 Pac. 834 (1927), where the borrower unsuccessfully argued lack of consideration for the agreement to pay a prepayment penalty. 
ment, in California ${ }^{19}$ and elsewhere, ${ }^{20}$ has been uniformly rejected. ${ }^{21}$

The allegation of usury ${ }^{22}$ has arisen when the prepayment penalty added to the actual interest paid was equal to a sum in excess of the maximum lawful interest calculated to the date of prepayment. ${ }^{23}$ In such cases the borrower has sought relief under the state usury laws. ${ }^{24}$ The cases, ${ }^{25}$ in holding that the amount of the prepayment penalty cannot be included in interest to determine usury, have adopted two distinct lines of reasoning. In non-option situations the courts have reasoned that the prepayment charge was not interest but merely the consideration for a new argreement to allow prepayment. ${ }^{26} \mathrm{In}$ option situations $\mathrm{s}^{27}$ the courts, faced by the fact that the amount of the penalty was actually a part of the loan agreement, have stressed the borrower's control over the time of prepayment. Since it is the borrower's voluntary act of prepayment which precipitates the penalty, the courts have concluded that the borrower should not have the power to create a usurious loan by prepayment. ${ }^{28}$ Present, however, in both types of penalty cases

19 French v. Mortgage Guar. Co., 16 Cal.2d 26, 104 P.2d 655 (1940) (option); Abbot v. Stevens, 133 Cal. App. 2d 242, 284 P.2d 159 (1955) (option); Grall v. San Diego Bldg. \& Loan Ass'n, 127 Cal. App. 250, 15 P.2d 797 (1932) (non-option); McCarty v. Mellinkoff, 118 Cal. App. 11, 4 P.2d 595 (1931) (non-option).

20 For a compilation of national authority on the question of prepayment penalties as constituting usury, see Annot., 130 A.L.R. 73 (1941); Annot., 75 A.L.R.2d 1265 (1961); 55 Axr. JUR. Usury \$ 47 .

21 As a commentary on the equities it might be noted that several lower courts have held against the lender, in the face of contrary authority, only to be reversed on appeal. One New York Supreme Court judge reasoned that the law must provide some sort of protection from excessive prepayment penalties, and then unsuccessfully tried to show that the usury laws afford that protection. See Feldman v. Kings Highway Sav. Bank, 102 N.Y.S.2d 600, 603-04 (Sup. Ct. 1950), rev'd, 278 App. Div. 589, 102 N.Y.S.2d 306, aff'd mem., 303 N.Y. 675, 102 N.E.2d 835 (1951).

22 For a general discussion of usury and a history of usury legislation in California see Coffin, Usury in California, 16 CALIF. L. REv. 281 \& 387 (1928); Warren, Regulation of Californic Housing Finance, 8 U.C.I.A.L. REv. 555, 561-80 (1961).

23 The current maximum lawful rate of interest on a real property loan in California is 10\%. Car. Const. art. XX, § 22; CaI. Bus. \& Prof. Cods $\$ 10242$ (c).

24 California usury regulation is found in various statutes and a constitutional amendment. The penalties for violation and general provisions are found in CAr. Crv. ConE \$§ 1916-1, 1916-2, 1916-3. The maximum lawful interest rate, and certain exemptions are set out in the California Constitution, CAL. Const. art. XX, $\$ 22$, and, according to the California courts, the entire legislative scheme with regard to certain real estate loans, was augmented by the Real Estate Loan Act of 1955 (CAL. Bus. \& Prof. CODE $\$ \$ 10240-48$ ). Sedia v. Elkins, 201 Cal. App. 2d 440, 20 Cal. Rptr. 278 (1962) ; Harris v. Gallant, 183 Cal. App. 2d 94, 6 Cal. Rptr. 630 (1960).

25 Authorities cited at notes 19, 20 supra.

26 For illustrative cases see McCarty v. Mellinkoff, 118 Cal. App. 11, 4 P.2d 595 (1931); Barringer v. Jefferson Standard Life Ins. Co., 9 F. Supp. 493 (E.D.S.C. 1935) ; Feldman v. Kings Highway Sav. Bank, 278 App. Div. 589, 102 N.Y.S.2d 306 (1951); Lyons v. National Sav. Bank, 280 App. Div. 339, 113 N.Y.S.2d 695 (1952). By lolding that the payment of the penalty was value given for a new right, these cases necessarily rest on the premise that the borrower has no right to prepay. See note 7 supra.

27 For recent cases involving prepayment penalty options see Foster v. Universal C.I.T. Credit Corp., 231 Ark. 230, 330 S.W.2d 288 (1959); Abbot v. Stevens, 133 Cal. App. 2d 242, 284 P.2d 159 (1955) ; Redunond v. Ninth Fed. Sav. \& Loan Ass'n, 147 N.Y.S.2d 702 (1955).

28 The California cases also rest, in part, on the general proposition that a loan unaffected by usury at its inception cannot become tainted by a subsequent agreement hetween borrower and lender. See Sharp v. Mortgage Sec. Corp., 215 Cal. 287, 9 P.2d 819 (1932); Knoll v. Echleussner, 112 Cal. App. 2d 876, 247 P.2d 370 (1952). However, if the payment of a prepayment penalty which would exceed the maxinum lawful interest was contemplated by the 
is the suggestion that usury would only exist if the lender received a total of interest and penalty charges in excess of the maximum lawful interest to the date of maturity.

The two approaches seem inconsistent. If the prepayment penalty is not interest but consideration for the agreement to terminate the loan, then there seems no justification for arriving at a limit for such penalties based on the maximum interest rate under the usury laws. But the inconsistent position taken by many state courts probably seemed the only way to resolve a dilemma. Had the courts not suggested some limit to the penalties, they would have endorsed a relatively simple means for circumventing the usury laws. ${ }^{29}$ On the other hand, had they held the prepaid loan usurious, the full sanctions of the usury laws would have been brought to bear on the lender. In California this would involve cancellation of all interest on the debt, ${ }^{30}$ and a recovery by the borrower of treble the annount of interest actually paid on the loan. ${ }^{31}$ Other states have even harsher sanctions, including forfeitures of both principal and interest by the lender. ${ }^{32}$

Perhaps the sanctions of the usury laws are too harsh to be invoked in the typical prepayment case. ${ }^{33}$ The prepayment penalty limit suggested in the usury cases, however, is no protection whatever to the prepaying borrower. ${ }^{34}$ The maxi-

parties at the time of entering the agreement, this argument becomes less than persuasive. See Haines v. Coinmercial Mortgage Co., 200 Cal. 609, 254 Pac. 956 (1927); Brown v. Cardoza, 67 Cal. App. 2d 187, 153 P.2d 767 (1944). Furthermore, the "voluntary prepaynnent" argument makes hittle sense when real estate turnover makes prepayment as much a necessity as borrowing. California rejects the "voluntary payment" doctrme, a means of estopping a borrower from claiming usury, when interest payments are involved. Taylor v. Budd, $217 \mathrm{Cal}$. 262, 18 P.2d 333 (1933) ; Janisse v. Winston Inv. Co., 154 Cal. App. 2d 580, 317 P.2d 48 (1957). In this hight it may be further questioned whether a voluntary prepayment should bar the claim of usury when a lender reaps inore than the maximuin lawful interest calculated to the date of prepayment.

29 Almost any rate of imterest could be "Iawfully" charged by merely including a prepayment penalty for the excess interest, and then setting up the loan for a far longer period than needed by the borrower. Of course, only when money was "tight" would a borrower agree to such a scheme, but then usury regulation is intended for just such times.

30 CAI. CIv. CODE $\$ 1916-2$ provides: "Any agreement or contract of any nature in conflict with the provisions of this section shall be null and void as to any agreement or stipulation therem to pay interest ...."

31 CAI. CIv. CODE $\$ 1916-3$ states that anyone having actually paid interest in excess of that allowed by $\S$ 1916-1 and 1916-2 may recover "treble the amount of money so paid or value delivered ...." As interpreted, the "lender forfeits all clain to interest, and the borrower may recover not ouly treble the excess, but treble the entire amount of interest actually paid on the loan ...." Haines v. Commercial Mortgage Co., 200 Cal. 609, 617, 254 Pac. 956, 958 (1927). Furthermore, the penalties of sections 1916-2 and 1916-3 apply to subsequently passed usury regulation notwithstanding the fact that those sections expressly refer only to violations of maximum rates set therem. Heald v. Friis-Hansen, 52 Cal.2d 834, 345 P.2d 457 (1959).

32 See Redfield, Could You Lose the Principal or Interest on Your Mortgage Investnents Because of Usury?, 75 BANKnng L.J. 737, 754-60 (1958).

33 Warren, supra note 22 , at 576.

34 Two recent cases in other jurisdictions, adopting the same reasoning as the California cases, demonstrate the lack of an effective judicial limit to prepayment penalty charges when usury is urged. In Feldman v. Kings Highway Sav. Bank, 278 App. Div. 589, 102 N.Y.S.2d $306(1950)$, a $\$ 2000$ penalty was enforced by the court on a prepayment of just over $\$ 15,000$. Upholding wbat amounted to a prepayment penalty of over $5 \%$ of the original principal, a Missouri court stated that "it is not usurious for a lender to require payment of interest, or a part thereof ... to the date of maturity of the note" as consideration for a right to prepay. Reich v. Pine Lawn Bank \& Trust Co., 356 S.W.2d 545, 549 (Mo. App. 1962). 
mum lawful interest less the interest already paid will always equal or exceed the lawful interest provided for by the loan less the interest paid. Practically, if the borrower were willing to pay the entire unearned interest, no question of prepayment riglits or penalties would ever arise. ${ }^{35}$

Moreover commercial banks and savings and loan associations (the two most important real estate lenders in California) are completely exempt from the California usury laws. ${ }^{36}$ If a judicial remedy is available to protect the prepaying borrower from excessive prepayment penalties, it does not appear to be usury. ${ }^{37}$

\section{B. A Possible New Attack}

\section{Background-Affirmative Relief from Penalties and Forfeitures}

The California courts seem embarked on a progressive course aimed at relieving contracting parties from the terms of any agreement which provides for what are, in effect, punitive damages for a default. ${ }^{38}$ While the policy against enforcing contractual penalties is well establisled by statute in California, ${ }^{30}$ until recent decisions involving land contracts the courts had not granted affirmative relief ${ }^{40}$

35 See note 8 supra.

36 CAI. Const. art. XX, $\$ 22$. This amendment authorizes the legislature to pass usury laws regulating the exempted institutions; the legislature, however, has not yet acted.

$3 \pi$ Even if the courts were to limit prepayment penalties to the maximum lawful rate of interest to the date of prepayment (as distinguished from the date of maturity), this would still permit penalties of an amount equal to the difference between the interest actually charged for the period of the loan and the maximum lawful rate of interest for tbat same period. On a $6 \%$ loan, this would amount to $4 \%$ of the declining balance of principal multiplied by the number of years the Ioan had been on the books.

38 The current case trend grantimg affirmative equitable relief to defaulting partics from contracts resulting in an imposition of punitive damages has been called the "Vendee's Era" since the vendee under land contracts has been the most frequent recipient of relief. See HetIand, California Land Contract, 48 CALIF. L. REv. 729, 732 (1960).

39 The entire field of contract recovery is almost completely governed by statute in California. Most of these statutes were enacted in 1872 and merely codified the common law, which, of course, included "equity's abhorrence of forfeitures." See Baum, Statutory Controls of Damages in Commercial Transactions, 12 Hastings L.J. 161 (1961). The statutes indicating the policy against punitive contract recovery are: CAL. Crv. CoDE $\$ 3300$, declaring the rule of perfect compensation-no more, no less-for a party aggrieved by a breach of contract; CaL. Crv. CoDE $\$ 3394$, limiting the awarding of exemplary damages to cases other tban those arising from a breach of contract; CAL. Crv. CODE $\$ 3275$, providing: "Whenever, by the terms of an obligation, a party thereto incurs a forfeiture, or loss in the nature of a forfeiture, by reason of his failure to comply with its provisions, he may be rehieved therefrom, upon making full coinpensation to the other party, except in cases of a grossly negligent, willful, or fraudulent breach of duty."; Cax. CIv. CODE $\$ 3369$, stating that "Neither specific nor preventive relief can be granted to enforce a penalty or forfeiture in any case . . ." Related to the aforementioned sections are CAL. CIv. CODE $\$ \S 1670$ and 1671 . Under these sections any attempt to liquidate damages in advance of a breach of contract is void unless it can be shown that it would be impracticable or extremely difficult to $f x$ the actual damage. These sections recognize that hquidated damage clauses often hide penalties. See 5 Corbin, Contracts 280 (1951).

40 Of course, the California courts have always construed contract provisions so as to avoid a forfeiture wherever possible. E.g., New Liverpool Salt Co. v. Western Salt Co., 151 Cal. 479, 91 Pac. 152 (1907). And even where a forfeiture was clearly called for by the terms of an agreement, equity would not enforce it if some "waiver," "estoppel" or other bar against enforcement could be found. E.g., Boone v. Templeman, $158 \mathrm{Cal}$. 290, 110 Pac. 947 (1910). Where, however, no bar could be found, or where the parties expressly made time of the essence, 
from contractual penalties and forfeitures.11 With Barkis v. Scott, ${ }^{42}$ in 1949 , the California Supreme Court began to formulate a consistent policy against forfeitures resulting in punitive damages. A vendee who had "innocently" defaulted on a payment under a installment land contract was allowed to reinstate the contract, thus averting the "forfeiture" he would have suffered if his vendor had been able to quiet title and retain the installment payments made to the date of the default. ${ }^{43} \mathrm{It}$ was held that California Civil Code Section $3275{ }^{44}$ standing alone, precluded the forfeiture of the installment payments and allowed the non-willfully defaulting vendee the right either to recover his previous payments above the vendor's actual damages, or to reinstate the contract by curing the default.

Just one year after Barkis it was argued in Baffa v. Johnson ${ }^{45}$ that even a willfully defaulting vendee, specifically excluded from the protection of section 3275 , deserved affirnative relief from a forfeiture of his down payment. The vendee argued that the vendor would be himited to compensatory relief in a suit for damages. ${ }^{46}$ Furthermore, the vendor would not be entitled to any specific relief without first making restitution of any penalties. ${ }^{47}$ Since no penalty could be recovered if the vendor sued, the same result should be reached in a suit brought by the defaulting vendee for the restitution of any penalties. While the supreme court was receptive to the argument, no relief was granted. The vendee had not

no relief would be granted. Henck v. Lake Hemet Water Co., 9 Cal. 2 d 136, 69 P.2d 849 (1937). In many cases equity actually enforced a forfeiture by quieting a vendor's title after a default by a vendee in an installment land contract without granting restitution of any part of the installments already paid on the purchase price. See Schwerin Estate Realty Co. v. Slye, 173 Cal. 170, 159 Pac. 420 (1916); Oursler v. Thacher, 152 Cal. 793, 93 Pac. 1007 (1908); cf. Pitt v. Mallalieu, 85 Cal. App. 2d 77, 192 P.2d 24 (1948).

41 The legal forfeiture, as it existed prior to the new line of California cases, was aptly described by Professor Ballantine:

The law, while looking with rigliteous abhorrence on forfeitures, and washing its liands of their enforcement, after the manner of Pontius Pilate, yet lias been reluctant to intervene with affirmative relief or to formulate any consistent primciple condemning the validity of cut-throat provisions which in their essence involve forfeitures. Although the law will not assist in the vivisection of the victim, it will often permit the creditor to keep his pound of flesl if he can carve it for himself.

Ballantine, Forfeitures for Breach of Contract, 5 MnN. L. REv. 329, 341 (1916).

4234 Cal. 2d 116, 208 P.2d 367 (1949).

43 Prior to Barkis, quieting title and retaining the vendee's payments was a common remedy for the vendor under the installment contract. The vendor could also sue for damages, seek specific performance, do nothing and merely retain the property and the moneys paid, or, if lie were generous, rescind the contract. Glock v. Howard \& Wilson Colony Co., 123 Cal. 1, 55 Pac. 713 (1898). See Comment, 27 CAIrF. L. REv. 583 (1939), for a similar list of vendor's remedies.

44 See note 39 supra.

4535 Cal. 2d 36, 216 P.2d 13 (1950).

46 CAL. Crv. CODE $\$ 3307$ provides that the measure of damages for a vendee's breach of an agreement to purchase real property is "the excess, if any, of the amount which would lave been due to the seller, under the contract, over the value of the property to him." In addition the seller can recover incidental out-of-pocket expenses. Royer v. Carter, $37 \mathrm{Cal}$. 2d 544, 550, 233 P.2d 539, 543 (1951). However, it slould be noted that this measure is really intended for the breach of a buy-sell agreement. Something akin to the rental value of the property would be more applicable to the breach of an installment contract. See Hetland, California Land Contract, 48 CaIfF. L. Rev. 729, 769 (1960). Cf. Ward v. Union Bond \& Trust Co., 243 F.2d 476 (9th Cir. 1957).

47 This result, it was argued, would be dictated by CAL. CIv. CoDE $§ 3369$ : "Neither specific nor preventive relief can be granted to enforce a penalty or forfeiture in any case ...." 
sustained his bnrden of proving that the forfeited down payment exceeded the vendor's actual damages. ${ }^{48}$

In Freedman v. The Rector, ${ }^{49}$ however, an intentionally defaulting vendee was able to prove that the vendor suffered only incidental losses, and that to allow him to retain a 2,000 dollar down payment would be to enforce a forfeiture resulting in punitive damages. The supreme court granted restitution, relying on California's policy against the imposition of punitive damages, ${ }^{50}$ and the reasoning of Baffa. ${ }^{51}$

The Ninth Circuit rounded the Barkis-Freedman picture in Ward v. Union Bond \& Trust $\mathrm{Co}^{52}$ by holding that under California law a willfully defaulting vendee was not limited to restitution but could specifically enforce the contract against his vendor. The vendee was permitted to reinstate the installment land contract, pay the remaining balance without penalty, and obtain clear title to the property.

It seems clear that the Freedman principles are sound. The underlying theory, based on notions of unjust enrichment, is fundamental: In case of breach of contract, for whatever reason, justice requires nothing more than compensation measured by the amount of harm suffered. ${ }^{53}$

While the Freedman rule arose in the context of the land contract, its application is by no means himited to such transactions. ${ }^{54}$ Cases involving such diverse forfeitures as a partner's interest in a general partnership agreement, ${ }^{, 55}$ a buyer's rights in a conditional chattel sales contract, ${ }^{56}$ and an interest in a state liquor hicense and bar ${ }^{57}$ have all applied Freedman in order to justify appropriate relief from a penalty arising under the terms of an agreement. Neither the posture of the case, ${ }^{58}$ nor the form of the penalty ${ }^{59}$ will prevent the court from granting relief, if, in fact, the defaulting party must pay,more than just compensation for the losses caused.

48 The party seeking affirmative relief under the principles of the cases discussed will always have the initial burden of showing that the amount of the forfeiture or penalty exceeded the amount of damages sustained by the other party. Bird v. Kenworthy, 43 Cal. 2d 656, 277 P.2d 1 (1954); Baffa v. Johnson, 35 Cal. 2d 36, 216 P.2d 13 (1950); Pasteur Realty Corp. v. La Fleur, 154 Cal. App. 2d 5, 315 P.2d 374 (1957); Petersen v. Ridenour, 135 Cal. App. 2d 720, 287 P.2d 848 (1955).

4937 Cal. 2d 16, 230 P.2d 629 (1951).

50 Id. at $21-22,230$ P.2d at $634-35$. "To permit what are in effect punitive damages ... is inconsistent with section 3294 of the Civil Code limiting the right to exemplary damages and sections 1670 and 1671 dealing with hquidated damages."

51 Id. at 22,230 P.2d at 635 . "Unless the same rule [restitution of penalty when vendor sues to quiet title] is adopted when the vendee seeks restitution, the rights of the parties under identical fact situations will turn on the chance of which one first seeks the aid of the court."

62243 F.2d 476 (9th Cir. 1957). But see Crofoot v. Weger, 109 Cal. App. 2d 839, 241 R.2d 1017 (1952) (court allowed restitution hut refused reinstatement).

535 CORBIn, Contracts 280 (1951).

54 "That principle [affirmative rehef from penalties-Freedman] extends beyond real estate transactions and applies in a variety of situations to avoid unjust enrichment." Harriman v. Tetik, 56 Cal. 2d 805, 811, 366 P.2d 486, 489, 17 Cal. Rptr. 134, 139 (1961).

55 Hill v. Hearron, 113 Cal. App. 2d 763, 249 P.2d 54 (1952).

56 Bird v. Kenworthy, 43 Cal. 2d 656, 277 P.2d 1 (1954).

57 Harriman v. Tetik, 56 Cal. 2d 805, 366 P.2d 486, 17 Cal. Rptr. 134 (1961).

58 See note 51 supra.

69 Rodriguez v. Barnett, 52 Cal. 2d 154, 338 P.2d 907 (1959); Scarbery v. Bill Patch Land \& Water Co., 184 Cal. App. 2d 87, 7 Cal. Rptr. 408 (1960). 


\section{Applying Freedman to Protect the Prepaying Borrower}

The Freedman principles may provide courts with a means of granting the borrower relief from excessive prepayment penalties without encountering the difficulties inherent in an application of the usury laws.

\section{a. The Direct Application of Freedman}

A direct application of Freedman requires that prepayment be construed as a default in the borrower's obligation to make continued payments under the loan contract. If such a construction is possible, then a borrower compelled to pay a sun in excess of the actual loss suffered by the lender should be entitled to restitution on the theory that the lender, if he sued, would be unable to recover the penalty. ${ }^{60}$

In the non-option penalty, a direct application might be difficult since the actual agreement to pay a penalty is reached independently of the loan contract. In the option penalty cases, the stipulated sum can be construed as either damages fixed by contract in anticipation of breach, or as merely an alternative means of performance. ${ }^{01}$ The distinction involves drawing a fine hine. ${ }^{62}$ Having no right to prepay, the borrower can argue that he is paying hquidated damages to terminate the contract. ${ }^{33}$ On the other hand, the lender can argue that prepayment is not a breach since the loan agreement is merely being performed according to its terms. Prepaying the amount called for by the agreement satisfies the entire obligation, while an unaccepted tender of a lesser amount is ineffectual. ${ }^{64}$ Moreover, written acceptance of the principal and accrued interest as a satisfaction of the debt $^{65}$ wonld probably extinguish the debt and the lender would have no cause of action to recover the penalty.

A formal analysis does not seem to provide an adequate answer. Two recent Cahfornia penalty cases, however, seem to indicate that the Califorina courts would approach the problem by mimimizing the formal considerations, and by determining the nature of an alleged penalty provision strictly in relation to the circumstances of its payment. ${ }^{66}$ In other words, the justification for, and reason-

00 This argument would be an application of the "turn-about" reasoning of Baffa-Freedman. See note 51 supra and accompanying text.

61 See 5 Corbin, Contracts $\$ 1070$ et seq. (1951), for a discussion of the distinction between liquidated damage clauses and provisions for alternative performance.

62 Ibid. For California cases see, e.g., Royer v. Carter, 37 Cal. 2d 544, 233 P.2d 539 (1951); Smith v. Carlston, 205 Cal. 541, 271 Pac. 1091 (1928); Dittrich v. Gobey, 119 Cal. 599, 51 Pac. 962 (1898).

63 Once it is determined that a prepayment penalty option is, in fact, a provision for liquidated damages, the California statutes control. CAL. Crv. CoDE $\$ 1670$ provides: "Every contract by which the amount of damages to be paid, or other compensation to be made, for a breach of an obligation, is determined in anticipation thereof, is to that extent void, except as expressly provided for in the next section." CAL. Crv. CodE $\$ 1671$ continues: "The parties to a contract may agree therein upon an amount which shall be presumed to be the amount of damages sustained by a breach thereof, when, from the nature of the case, it would be impracticable or extremely difficult to fix the actual damages."

CA CAI. CIv. CoDE $\$ 1486$ states: "An offer of partial performance is of no effect." See authority at note 8 supra and accompanying text.

65 See Car. Crv. Code $\$ \S 1521,1522$ for the Califorma approach to accord and satisfaction.

${ }^{66}$ Compare Scarbery v. Bill Patch Land \& Water Co., 184 Cal. App. 2d 87, 7 Cal. Rptr. 408 (1960), with Folden v. Lobrovich, 171 Cal. App. 2d 627, 341 P.2d 368 (1959). The comparison points towards a tentative conclusion that the courts, in distinguishing liquidated damage 
ableness of, an alternative amount to be paid under a contract will determine whether it represents security against a breach or a valid means of alternative performance. A stiff prepayment penalty option implies a penalty to prevent prepayment; a more reasonable sum suggests a true optional means of performance. Under such an analysis of the prepayment option, the key to a direct application of Freedman may be a determination of whether the lender's losses or expenses justify the use of prepayment penalties.

The lender claims two direct losses when the borrower prepays: (1) the loss of earnings through giving up an investment before maturity, and (2) the unamortized overhead costs of making the loan. Moreover, lenders suggest that without prepayment penalties borrowers would cash-out their loans whenever interest rates dropped. If substantiated by fact, each of the foregoing claims would probably justify some sort of prepayment charge; however, as applied to an excessive charge, each argument is subject to attack. First, if the sum charged exceeds the lender's actual lost earnings (interest on idle capital until a new loan can be made) ${ }^{67}$ then the charge is merely a hidden source of revenue ${ }^{68}$ anticipated by lenders aware of the high mortgage loan turnover. When the lender's principal is restored along with earned interest and his out-of-pocket losses, it would seem

clauses from alternative performance provisions, will weigh the amount of the alleged penalty in relation to the value received by the party suffering the penalty and the losses incurred by the other party. In Scarbery, a defaulting vendee was granted affirmative relief on a land contract even though, by the terms of the agreement, he had a "true option" in form, and was not obligated to purchase the property. The court reasoned that the amount the vendee would have had to pay for his purchase "option" was so great in relation to the value of the property, that the trial court properly found the "option" payment to be security for an implied obligation to purchase the property, and not a substitute or alternative performance. 184 Cal. App. 2d at 101, 102, 7 Cal. Rptr. at 417. In Folden, however, the court fouud that a deposit on a lease agreement, which was forfeited when the lessee failed to obtain collateral leases, was not a provision for liquidated damages in the event of a breach, but was "consideration for a right granted the plaintiffs [lessees] to be reheved of their obhgation under the contract ...." 171 Cal. App. 2d at 629, 341 P.2d at 369. Even though the parties treated the forfeited sum as hiquidated damages, the amount "forfeited" in relation to the rental value of the property and the obligations of the lessor for the period in which the lessee had a reservation on the property, imdicated that the parties intended the money to be paid as an alternative means of performing the contract, and not as security for performance of the lease.

67 The lender's claim of lost earnings, or interest on the prepaid primeipal until it is reloaned, is not intended as a suggested measure of a lender's damages, but only as an indication of the unjustified nature of an excessive penalty charge. If it would be the measure of damages, the uncertainty of trying to accurately calculate such a loss may support an argument for the validity of a clause liquidating the danages. See discussion in note 69 infra. It may also be argued that the measure of damages could be the present value of the full unearned interest since the lender, with a theoretically inexhaustable supply of money to lend, would not be under a duty to mitigate daunages by re-lending the identical money prepaid. Both of these measures, however, seem unrealistic, and contrary to analogous law. CAx. Civ. CodE $\$ 3302$ provides that "the detriment caused by the breach of an obligation to pay money only, is deemed to be the amount due by the terms of the obligation with interest thereon. Civil Code $\$ 3289$ provides: "any legal rate of interest stipulated by a contract remains chargeable after a breach thereof, as before, until the contract is superseded by a verdict or other new obligation." Thus, in the case of a breach of the terms of a mortgage loan by non-payment, the lender may only recover interest at the contract rate until the date of the verdict, the unpaid prineipal, and perhaps incidental costs incurred by the lender. $C f$. Phelps v. Mayer, $126 \mathrm{Cal}$. 549, 550, 58 Pac. 1048 (1899); Bank of Am. Nat. Trust \& Sav. Ass'n v. Lane Mortgage Co., 18 Cal. App. 2d 431, 443, 63 P.2d 1189, 1195 (1937). The recovery for a prepayment "breach" slould be consistent.

68 See note 10 supra. 
unfair to allow the lender to collect an additional profit not actually bargained for as a cost of the loan. Second, lenders usually charge upwards of one and one-half per cent of the original principal as a fee for setting up a loan. Even if the lender's costs exceeded this amount in a given loan situation, a prepayment charge of a substantial percentage of the principal seems unjustified since it can be assumed that the costs of setting up a 10,000 dollar loan are relatively similar to establishing a 30,000 dollar loan. Finally, the use of the prepayment charge to deter refinancing at lower interest rates is valid only when interest rates are in fact declining or are lower than the rate on the original loan. The lender cannot complain when interest rates are higlier. Furthermore, even absent a prepayment penalty, the fees for setting up loans serve as a check against refinancing.

A borrower prepaying wlien interest rates are equal to or above the rate of his loan who is forced to pay a penalty of three, four or five per cent of the original principal, slould have hittle trouble in showing that such a charge is unjustified. This fact alone should indicate that the penalty option was intended not as an alternative means of performance, but as security for performance of the borrower's full term obhigations. In such a case, Freedman principles could be directly applied to reheve against the excessive annount charged. ${ }^{69}$

\section{b. An Indirect Application of Freedman}

The borrower must overcoine certain technical difficulties in arguing a direct Freedman approach to the prepayment option penalty. Furthermore, this approach would not appear available to the borrower faced with a non-option penalty. Thus an application of Freedman restricted to option situations would probably have the effect of encouraging lenders to dispense with prepayment options and rely on their right to refuse prepayment. In order to establish the basis for a broader application of Freedman principles, it is necessary to consider prepayment in conjunction with its counterpart, the default in payment.

In order to obtain a discharge of the mortgage or deed of trust encumbering his property before maturity, the prepaying borrower will attempt to satisfy his debt. ${ }^{70}$ Satisfaction, under a typical deed of trust note, means payment of the unpaid principal, the accrued or earued interest to the date of repayment, and whatever penalty charge is provided for in the note, or demanded by the lender. As previously discussed, the reasoring in the usury cases leads to the conclusion that there is presently no meaningful hinit to the amount of the mortgage prepayment charge. ${ }^{71}$

${ }^{60}$ Once it is established that a prepayment penalty option is not an alternative means of performance but a liquidated damage clause, it must still be shown that the clause is not valid under Cax. Crv. CoDE $\$ 1671$ (cited in note 63 supra). Under the better view of testing the validity of liquidated damage clauses, the impracticality of fixing actual damages is to be measured at the time of the contract, Better Food Mkts. v. American Dist. Teleg. Co., $40 \mathrm{Cal} .2 \mathrm{~d}$ $179,185,253$ P.2d 10, 14 (1953), and the amount chosen must bear some reasonable relation to the probable actual loss, Rice v. Schmid, 18 Cal.2d 382, 115 P.2d 498 (1941). It may well be that the uncertainties of determining a lender's actual loss through prepayment merit a valid liquidated damage clause. If, lowever, a borrower is able to prove the existence of a liquidated damage clause by showing that it is too excessive to be considered a means of alternative performance, lie may also have thereby established the mvalidity of such a clause by the lack of relationship to the probable loss.

70 CAI. Crv. CODE $\$ 2941$ requires that a mortgage be discharged upon satisfaction of the secured debt. There are criminal penalties for not so discharging it. Car. Crv. CoDE $\$ 2941.5$.

${ }^{71}$ See notes 34 and 37 supra and accompanying text. 
The law seems to offer the borrower who willfully defaults on his mortgage payment far more protection from excessive charges by his lender than is provided the prepaying borrower. Most mortgage agreements provide that in the event of a specified default by the borrower, the lender may declare the entire loan due. ${ }^{72}$ If the borrower fails to pay the accelerated debt, the lender may proceed for the full secured amount. ${ }^{73}$ While the lender need not accelerate the entire debt, ${ }^{74}$ as a result of certain California statutes it is highly unlikely that a lender could limit his recovery to the particular default. Section 726 of the California Code of Civil Procedure requires an action against the property (mortgagor's interest in the property) in order to recover on a debt secured by a mortgage. ${ }^{75}$ Section 728 of that same code provides that upon default of the payment of an installment, only so much of the property shall be sold as is needed to satisfy the amount due; but that: "If the property cannot be sold in portions, without injury to the parties, the whole may be ordered sold in the first instance, and the entire debt and costs paid ...." Thus unless the property can be divided without economic waste, the California lender seeking redress for the borrower's default in payment is necessarily channeled into an acceleration of the debt. When the lender does accelerate by some affirmative act, such as the filing of an appropriately worded complaint in a foreclosure by action, or a notice of default in a non-judicial sale, ${ }^{70}$ the borrower has a statutory period of time within which to either cure the default and reinstate the loan, ${ }^{77}$ or pay off the entire accelerated amount due. ${ }^{78}$

72 See Osborn, Mortgages $\S 326$ (1951); 1 Jones, Mortgages $§ 94$ (8th ed. 1928).

73 Ibid.

74 An acceleration clause is never self-operative even though stated as such in the loan agreement. There must always be some affirmative act by the lender to invoke the actual acceleration of the debt. Jones v. Wilton, 10 Cal. 2d 493, 75 P.2d 593 (1938); Andrews v. Zook, 125 Cal. App. 19, 13 P.2d 518 (1932). But if no action is taken, the statute of limitations begins to run on the default. CaL. Code Crv. Proc. $\$ 337$.

75 CaL. Code Crv. Proc. $\$ 726$ provides: "There can be but one form of action for the recovery of a debt, or the enforcement of any right secured by a mortgage on real or personal property ... . In such action the court may, by its judgment, direct the sale of the encumbered property." Until there lias been resort to the security, no personal action may be maintained. See Barbieri v. Ramelli, 84 Cal. 154, 23 Pac. 1086 (1890).

${ }^{76}$ Any positive assertion of the riglit to accelerate would probably be sufficient to make the entire debt due; lowever, because CAL. CIv. CODE $\$ 2924$ requires the filing of a notice of default as the first step in a non-judicial proceeding to "sell or cause to be sold such property to satisfy the obligation," the election to accelerate is normally made at this point. See Wilhams v. Koenig, 219 Cal. 656, 28 P.2d 351, 352 (1934); Sohn v. Cahforma Pac. Title Ins. Co., 124 Cal. App. 2d 757, 763, 269 P.2d 223, 228 (1954). Similarly, the election to accelerate is normally made by the filing of the complaint in a judicial foreclosure proceeding. See Title Guar. \& Trust Co. v. Fraternal Fin. Co., 220 Cal. 362, 364, 30 P.2d 515, 516 (1934); Wilkams v. Gordon, 205 Cal. 590, 592, 271 Pac. 1070, 1071 (1928).

77 CAL. Crv. CODE $\$ 2924$ (c) provides that at any time within nimety days from the filing of the notice of default, if a power of sale is to be exercised, or at any tine prior to the entry of the decree of forcclosure, any person with an interest in the mortgaged property may pay the arrearages and costs of the default and reinstate the inortgage or trust deed without suffering acceleration.

$78 \mathrm{It}$ may be argued that CAI. Crv. CODE $\$ 2924(\mathrm{c})$, sce note 77 supra, restricts the borrower to curmg his default and reinstating the loan even after the lender elects to accelerate. Apart from the practical fact that a borrower could default and reinstate until his liarrassed lender pleaded for full payment, such an interpretation of the statute would seem incorrect. First, \$ 2924(c) was passed in 1933, Cal. Stat. 1933, ch. 642, p. 1671, \& 3, to allow defaulting borrowers an opportunity to avoid foreclosure by paying up only the aunount of the default when they 
In the acceleration situation, California law would seem to protect a borrower from any penalty analogous to an excessive prepayment charge. The overwhelming California authority holds that acceleration of a secured debt, as sucll ${ }^{79}$ is not in the nature of an invalid penalty. ${ }^{80}$ This authority, however, only establishes a right to accelerate the unpaid principal and earned interest to the date of actual payment. ${ }^{81}$ The California Supreme Court has yet to pass directly on the right of a lender to accelerate all or a portion of unearned interest as a penalty for default. ${ }^{82}$ However, courts of other jurisdictions have held that acceleration clauses

were unable to pay the total amount of the accelerated debt. It would seem foolish to interpret a statute purporting to increase the alternatives available to the defaulting borrower as depriving him of an alternative that he obviously had prior to the statute. Second, allowing the lender the power to refuse tender of an amount which he bas declared due seems basically unfair, especially if a borrower were to change his position in order to comply with the lender's demand. In addition, such a power of refusal would seem inconsistent with CAL. Crv. Code $\$ 1500$, providing for the satisfaction of a due debt by depositing the amount due in a commercial bank. Since the lender may foreclose for the full amount, the debt is certainly due. The lender should not be able to refuse tender. $C f$. Trinity County Bank v. Haas, $151 \mathrm{Cal}$. 553, 91 Pac. 385 (1907). Third, under $\$ 2924$ (c), the borrower is only entitled to reinstate before the entry of the foreciosure decree in a judicial proceeding, or before the lapse of ninety days from the filing of a notice of default in a non-judicial proceeding. Thus an interpretation of $\$ 2924$ (c) himiting the horrower to reinstatement would mean that, in the case of a judicial proceeding, after the entry of the foreclosure decree, but before the actual sale of the property, the borrower would have no redemption rights. Under California law, the lender may delay the sale ten years or longer, CAL. Crv. CoDE $\S 685$, and the borrower would be powerless to pay off the judgment and discharge the hen. While there appear to be no California cases, the common law is that the equity of redemption is not barred until the foreclosure sale is consummated. 2 JonEs, MorTGAGES $\S 1350$ at 816 (8th ed. 1928) ; Brown v. Frost, 1 Hoff. N.Y. 41 (1839). Assuming this to he the Califorma rule, a restrictive interpretation of $\$ 2924$ (c) would be untenable.

$79 \mathrm{~A}$ recent case bas held that acceleration, as such, is in the nature of a forfeiture or penalty, and entitles the borrower to affirmative relief. Bisno v. Sax, 175 Cal. App. 2d 714, 346 P.2d 814 (1959). The authority cited by the court in reaching its decision does not support the opimion, however, and the case has been rejected by another district court of appeal. Green v. Carlstrom, 212 A.C.A. 237, 27 Cal. Rptr. 850 (1963). Furthermore, in light of the protection given the borrower under CAL. Crv. CoDE $\$ 2924$ (c), see -note 77 supra, judicial rehef from acceleration, as such, would seem unnecessary.

80 Whitcher v. Webb, 44 Cal. 127 (1872); Righetti v. Monroe, Lyon \& Miller, Inc., 109 Cal. App. 333, 293 Pac. 114 (1930) ; Young v. Burchill, 96 Cal. App. 338, 274 Pac. 379 (1929); Jump v. Barr, 46 Cal. App. 338, 189 Pac. 334 (1920); Dunn v. Barry, 35 Cal. App. 325, 169 Pac. 910 (1917). Cahfornia is in accord with the general law; see 36 AMr. JUR. Mortgages \$385 (1943); OSBORNE, MortGages § 326 (1951).

81 Although techmically there is a forfeiture of credit when a debt is accelerated, and the value of the credit may exceed the lender's actual damages, Freedman has not been held applicable when only the primcipal and earned interest are accelerated. Green v. Carlstrom, 212 A.C.A. 237, 27 Cal. Rptr. 850 (1963); Messner v. Mallory, 107 Cal. App. 2d 377, 236 P.2d 898 (1951). It should also be noted that the issue of a penalty in the cases cited at note 80 supra, dealt not with affirmative relief for the borrower, but rather with the possibility of barring enforcement of the lender's acceleration remedy for default.

82 Lenders interviewed could not recall a case in which an attempt was made to collect a penalty of unearned interest upon the acceleration of a mortgage debt. Furthermore, inost lenders use a form note which calls for "interest on the declining balance of the principal sum until paid," and thus probably have no basis for a claim to unearned interest upon acceleration. Regulations of the Federal Housing Administration would prohibit charging an acceleration penalty on an FHA insured loan. 24 C.F.R. 207.253 (1962). These factors explain the lack of Cahifornia cases on the issue of accelerating unearned interest. The California courts also seem to proceed on the assumption that an acceleration clause only accelerates the unpaid principal and earned interest. See cases cited at note 67 supra. 
will not be enforced as to any part of unearned interest. ${ }^{83}$ This rule has been recognized by a California district court of appeal in Steffen $v$. Refrigeration Discount Corp. ${ }^{84}$ where a defaulting borrower was allowed restitution of unearned interest paid to obtain the discharge of his mortgage after acceleration. In answer to the argument that the lender had a right, under the express terms of the agreement, to accelerate the unearned interest, the court indicated that California law would prohibit the acceleration of more than the unpaid principal and earned interest. ${ }^{85}$ Moreover, the defaulting borrower should fall plainly within the Freedman rule. Any lender collecting a penalty from a defaulting borrower on the basis of an acceleration clause would be subject to a suit by the borrower for the restitution of the amount of the penalty in excess of the actual damages suffered by the lender. ${ }^{86}$

It is not advisable that default be used as a means of prepaying since it would involve certain costs, a loss of time, and the risk of losing credit standing. ${ }^{87}$ However, comparison of prepayment and default leads to the conclusion that the defaulting borrower who cuts short the term of his loan is protected from penalty charges, while the borrower who cuts short his loan by prepayment is not protected. Thus any prepayment charge in excess of the lender's actual losses takes on the nature of a penalty, and it becomes moot whether or not the act of prepayment can be considered a breach of the loan agreement. If the collection of such an excessive prepayment penalty could be deemed wrongful under the principles of Freedman, then a borrower compelled to pay the penalty, in order to secure the discharge of his mortgage, could make payment under protest, and maintain a suit for restitution. ${ }^{88}$ It should make no difference whether the penalty is an

83 In the Matter of Mill City Plastics, 129 F. Supp. 86 (D.C. Minn.), aff'd 226 F.2d 212 (8th Cir. 1955); Holman v. Hollis, 94 Fla. 618, 114 So. 255 (1927); A-Z Servicenter, Inc. v. Segall, 334 Mass. 672, 138 N.E.2d 266 (1956); Dugan v. Lewis, 79 Tex. Ct. App. Dec. Civ. 246, 14 S.W. 1024 (1891); 36 AM. Jur. Mortgages $\$ 386$ (1943); cf. Armstrong v. Alliance Trust Co., 88 F.2d 449, 452 (5th Cir. 1937); Cissna Loan Co. v. Gawley, 87 Wash. 438, 151 Pac. 792 (1915).

8491 Cal. App. 2d 494, 205 P.2d 727 (1949).

85 Id. at 497,205 P.2d at 728 . Technically the court based restitution on a theory of duress, holding that since the lender had no right to the unearned interest, the protested payment, in light of the alternative of risking foreclosure, was made under duress. See also Leeper v. Beltrami, 53 Cal. 2d 195, 347 P.2d 12 (1959).

86 Were Freedman applied, it would make no difference whether the lender sued to accelerate the unearned interest, or the borrower paid the unearned interest and then sued for restitution. See note 51 supra.

87 Attorney's fees due on a default are limited by statute. CAL. Crv. Code § 2924(c). The maximum allowed on a trust deed is the greater of $\$ 50$ or $1 / 2$ of $1 \%$ of the unpaid principal. On a mortgage the maximum is $\$ 100$. The more important deterrent to defaulting, however, is the possible loss of time, for a lender could conceivably delay acceleration for the full period of the statute of limitations without losing his right to any amount due. Furthermore, it sliould be pointed out that in certain commercial loan situations, the lender could thwart the borrower's attempt to force his lender to accelerate by enforcing a "rents and profits" clause and thereby delay the need to foreclose the lien on the real property.

88 Restitution could be founded on a theory of duress. See note 85 sicpra and accompanying text. Duress should not be too difficult to establish. The borrower seeking a discharge of his mortgage has no reasonable alternative but to pay the penalty demands of his lender. Thus, if the courts were to deem a lender's claim to an excessive prepayment penalty as a "false" or "wrongfnl" claim, the borrower would liave made a protested payment of a wrongful clain, having available no reasonahle alternative. See Leeper v. Beltrami, 53 Cal. $2 d$ 195, 204-05, 347 P.2d 12, 19 (1959). 
option or non-option type since protection would be based on the exaction of the penalty and not on a technical interpretation of the loan agreement.

If the courts would be willing to fashion some means of affirmative relief to the prepaying borrower, the borrower would still have the initial burden of proving that the penalty, as applied to him, was actually greater than the lender's losses. ${ }^{89}$ Some of the grounds on which the amount of the penalty could be challenged have already been discussed..$^{90}$ But necessarily the point at which the borrower would make a prima facie case will be uncertain until the question is litigated.

\section{III}

\section{A STATUTORY RIGHT TO PREPAY}

Regardless of the possibility of judicial rehef to aid the unwary borrower, the root problem remains that until the basic law is changed, the right to prepay a mortgage loan must be secured from the lender. At least one state, New York, has enacted a statutory right to prepay mortgage loans from savings and loan associations. ${ }^{91}$ In addition to state enactments, federal loan regulations grant prepayment rights under all loans insured by the Veterans' Admimistration ${ }^{22}$ and the Federal Housing Authority. ${ }^{93}$ The Federal Home Loan Bank Board lias recently required that all federally chartered savings and loan associations allow their borrowers to prepay. ${ }^{24}$

The Califorma Legislature has demonstrated its awareness of the problems of prepayment by granting stautory prepayment rights in several loan situations. Under the Califorma Small Loan Law, ${ }^{95}$ borrowers may repay "in any amount ... at any time." The Unruh Act, ${ }^{96}$ regulating the retail installment contract, and the Rees-Levering Act, ${ }^{97}$ similarly regulating the automobile installment transaction, both contain prepayment rights. Real estate loans under the California Veterans' Farm and Home Purchase Act ${ }^{98}$ are also prepayable. Furthermore, the legislature has recently enacted legislation regulating sharp loan practices. The so-called Necessitous Borrower's Act of $1955^{\text {99 }}$ places himits on loan fees and other service cliarges, but for some reason leaves the prepayment penalty untouched.

Thus even with legislative activity in the real estate loan field, and with federal regulatory controls setting an example, the prepayment penalty, exacted by

80 See note 48 supra.

${ }^{90}$ See text accompanying notes 67-69 supra.

01 N.Y. BankING LAw art. $10 \$ 393(2)$. This act does allow for a modest prepayment charge.

92 Veterans' Administration loans may be prepaid "at any time, without premium or fee ...." 38 C.F.R. 36.4310 (1956).

93 F.H.A. insured loans provide for prepayment rights subject to a complex formula for an "adjusted premium," which, although amounting to a prepayment charge, can never exceed 1\%. 24 C.F.R. 207.253 (1962).

9412 C.F.R. 545.6-12 (1963).

95 CaL. FIN. Code $\$ 24473$.

${ }^{96}$ CaL. CIv. Code $\$ 1806.3$.

97 CAL. Crv. Code $\$ 2982$ (d).

98 CAI. MII. \& VET. CODE $\$ 987$, provides inter alia: "The purchaser on any installment date may pay any or all installments still remaining unpaid."

80 CaL. BUS. \& Prof. CODE $\$ \$ 10240-48$. As an amendment to the usury laws, these statutes in no way affect the exemption of institutional lenders. See note 24 supra. 
nearly all commercial lenders in California, has remained inviolate. Perhaps the threat of abuse is not enough to stir the legislature to action; however, a statute, which apparently would be unopposed by reputable lenders, ${ }^{100}$ could only improve the integrity of the real estate loan transaction. Simple in forn, it should merely declare a non-waivable ${ }^{101}$ right to prepay a mortgage loan subject to some reasonable prepayment charge, ${ }^{102}$ which could be exacted if, and only if, such charge were provided for in the loan agreement. ${ }^{103}$

\section{CONCLUSION}

The legal position of a borrower who wishes to pay off his mortgage before maturity is not enviable. The case law defining the basic rights of the parties gives the lender an advantage which is perhaps unjustified in a time when only a few isolated loans actually run until inaturity. If the average borrower were alert to the prepayment problein, competition among lenders might force them to grant more liberal prepayment rights; however, it appears that only sophisticated borrowers-a class rarely needing protection-ever actively negotiate prepayment terms at the time of niaking their loans.

It is not, however, the lender's initial advantage that creates the borrower's problem. Rather it is the lack of a judicial remedy by which to himit penalty charges. The courts have held that usury law, for all practical purposes, is not apphicable, and the legislature, in granting prepayment rights in other loan fields, has ignored the secured real estate loan.

In light of recent developnents in California law, a borrower subjected to an excessive prepayment penalty may be able to seek an equitable remedy fashioned by analogy to the rehef granted from contracts imposing forfeitures or penalties upon default. Unless the legislature sees fit to act, the recent history of Cahifornia land contract cases demonstrates the likelihood that the courts will afford the borrower rehief where necessary.

Ellis J. Harmon

100 Most of the lenders interviewed expressed approval of some type of statutory regulation of prepayment.

101 If the right could be waived, the purpose of such a statute in aiding the unsophisticated borrower could be too easily defeated at the time of making the loan. Cf. CAL. Crv. CODE $\$ 2953$.

102 Loans in excess of a certain amount could be exempted from the maximum charge provisions on the theory that in such cases the parties should be able to bargain effectively for prepayment rights.

103 This limitation would reduce the risk that the unwary borrower would first discover the additional expense after he had entered into a contract to sell his home or property. 